\title{
Uma análise do materialismo histórico-dialético para o cenário da pós- verdade: contribuições histórico-críticas para o ensino de Ciências
}

\author{
Hélio da Silva Messeder Neto ${ }^{1}$ \\ Edilson Fortuna de Moradillo ${ }^{l}$ \\ Universidade Federal da Bahia \\ Salvador - BA
}

\section{Resumo}

Vivemos um momento de pandemia, a do coronavírus (Covid 19), e, ao mesmo tempo, um momento de grande perplexidade perante às alternativas que são colocadas para o seu enfrentamento, no qual o eixo condutor está sempre centrado nas preocupações com a reprodução do capital e com o mercado. Junto a isso, vivemos em um cenário de irracionalismo crescente em que discursos que desvalorizam o conhecimento científico são cada vez mais frequentes dentro e fora do ambiente acadêmico. Diante desse panorama, este artigo tem como objetivo fazer uma análise, a partir do materialismo histórico dialético, do cenário da pós-verdade e das implicações da relativização do conhecimento científico para o ensino de ciências. Para isso, resgatamos a categoria trabalho do materialismo histórico dialético e fazemos uma discussão sobre a prática como critério de verdade dentro do marxismo, mostrando como essas categorias podem nos ajudar a entender o contexto atual. Por fim, defendemos que neste cenário de crise estrutural do capital e irracionalismo, o ensino de ciências não pode se furtar de defender a verdade e disputar a concepção de mundo dos estudantes em sala de aula, de modo a apontar para uma outra sociedade não regida pela mercadoria.

\footnotetext{
${ }^{+}$An Analysis of historical-dialectical materialism for the post-truth scenario: historical-critical contributions to Science teaching

* Recebido: junho de 2020. Aceito: outubro de 2020.

${ }^{1}$ E-mails: helioneto@ufba.br; edilson@ufba.br
} 
Palavras-chave: Materialismo Histórico-Dialético; Pós-verdade; Ensino de Ciências.

\begin{abstract}
We live in a pandemic moment, that of coronavirus (Covid-19), and, at the same time, of great perplexity in the face of the alternatives that are placed to face it, where the driving axis is always centered on concerns about the reproduction of capital and the market. Along with this, we live in a growing irrationalism scenario where speeches that devalue scientific knowledge is increasingly common within and outside the academic environment. Given this scenario, this article aims to make an analysis, based on historical dialectical materialism, of this post-truth scenario and the implications of relativizing scientific knowledge for science teaching. For that, we rescued the work category from dialectical historical materialism and discussed the practice as a criterion of truth within Marxism, showing how these categories can help us understand the current scenario. Finally, we argue that this structural crisis scenario of capital and irrationalism, science education cannot be shied away from defending the truth and dispute the students' conception of the world in the classroom in order to point to another society not governed by commodity.
\end{abstract}

Keywords: Dialectical Historical Materialism; Post-truth; Science Teaching.

\title{
I. Introdução
}

Vivemos um momento de pandemia, a do coronavírus (Covid-19), e, ao mesmo tempo, um momento de grande perplexidade perante às alternativas que são colocadas para o seu enfrentamento, no qual o eixo condutor está sempre centrado nas preocupações com a reprodução do capital e com o mercado. Dessa forma, a vida passa a ser algo menor se comparada com as necessidades do capital e, quando é aparentemente valorizada, através de medidas de afastamento social e físico das pessoas, com o isolamento, no "fique em casa", e, logo depois, no "fique em casa se puder", tem como pressuposto maior e justificativa de não sobrecarregar e colapsar o sistema de saúde, geralmente já precarizado, sobretudo nos países periféricos do capital.

A Organização Mundial da Saúde (OMS) considera que o vírus Covid-19 se espalhou pelo mundo, por isso, podemos tratá-lo como uma pandemia. Infelizmente, por um caminho doloroso, a crise do coronavírus desnuda a essência das relações sociais reprodutoras do capital, dominante mundialmente, o qual é agravado nesse momento pela sua 
crise estrutural, em que os seus limites absolutos são ativados, alertando a humanidade para as contradições sociais que estamos vivendo: o ser humano fica dada vez mais subsumido ao capital e se torna peça descartável dessa engrenagem social, desse nosso sociometabolismo (MÉSZÁROS, 2006).

A vida em si, no nosso dia a dia, tem sido banalizada, principalmente para os milhões de trabalhadores do mundo inteiro que precisam vender a sua força de trabalho para sobreviver - esta é uma constatação fácil de fazer na pandemia e para além dela. A luta de classes mostra a sua cara cada vez mais através da ampliação das tensões sociais, expressa na ofensiva da retirada de direitos da classe trabalhadora e diminuição dos programas sociais; das péssimas condições de vida dos mais pobres; do crime organizado, miliciano ou não; e do desemprego crônico e estrutural, com repercussões sobretudo nos núcleos urbanos e periféricos das grandes cidades. Tudo isso é agravado pelos processos de corrupção, persistentes e sistêmicos, inerentes às relações reprodutoras do capital, evidenciando, e reforçando, as análises realizadas pelo campo marxista da lógica excludente da sociedade capitalista e sua crise estrutural de hoje.

Aqui no Brasil, o cinismo da classe dominante chega a tal ponto que "descobre", "de repente", os milhões de seres humanos sem as mínimas condições de sobrevivência; não é à toa que para minimizar e encobrir essas contradições postas na reprodução social gradativamente mais assimétrica, em que poucos acumulam enquanto a grande maioria fica de fora - eles utilizem do discurso ${ }^{2}$, da linguagem asséptica, para se referir a essas pessoas, abundando termos como: "os de menor privilégios", "os vulneráveis", "os desalentados", por exemplo. Do ponto de vista ideopolítico, essa linguagem utilizada é um reflexo da base material de uma sociedade cindida em classes e fundamentada na reprodução do capital, "sujeito" ativo das nossas determinações sociais, nas quais capital e trabalho se contrapõem, e o capital não pode existir sem o trabalho excedente, produtor de mais valia.

Ainda no cenário ideopolítico cultural do nosso tempo, é comum constatarmos, para muitos de modo estupefato, o avanço de concepções irracionalistas e que parecem absurdas

\footnotetext{
2 Aqui, tratando de forma rápida para não passar em branco, pois não teremos espaço para tratar da ideologia e da linguagem nesse texto, é bom perceber o papel que a ideologia pode desempenhar numa sociedade de classes e as formas como o pensamento tende a refletir a base material das relações sociais em que vivemos, com suas determinações sociais - a realidade objetiva -, isto é, o pensamento não tem autonomia absoluta; e, numa sociedade de classes, o pensamento dominante tende a ser o pensamento da classe dominante (MARX; ENGELS, 2007). Assim, a linguagem, como expressão do pensamento, não tem também uma autonomia própria, absoluta, como bem faz determinada perspectiva pós-moderna. Estas considerações reforçam as críticas realizadas por vários autores ao pós-modernismo, a exemplo de David McNally, quando aborda sobre "A língua e o novo idealismo" e trata no início do seu texto do pensamento pós-moderno: "Tudo é discurso, entendam; e o discurso é tudo. Uma vez que os seres humanos são criaturas linguísticas, uma vez que o mundo onde agimos é conhecido e descrito através da língua, esse novo idealismo alega que nada existe fora dela. A língua, o "discurso", o "texto" - o jargão varia, mas a mensagem não - define os limites do que conhecemos, do que podemos imaginar, do que podemos fazer." (McNALLY, 1999, p. 33). Neste texto, ele vai trazer a contribuição marxista para compreender a língua como partícipe das relações sociais historicamente configuradas e modeladas pelo trabalho e suas relações sociais constitutivas, em seu momento histórico assentado na luta de classes.
} 
neste período da história. Na rede social Facebook, existem comunidades que defendem a terra plana com quase 25000 pessoas inscritas ${ }^{3}$. Cresce, também, a participação de pessoas dos movimentos antivacina, governantes negando o aquecimento global e, no atual cenário de Covid-19, o presidente do Brasil, por exemplo, insiste no uso da cloroquina, mesmo que especialistas apontem a necessidade de mais estudos diante do medicamento. Nos grupos de WhatsApp, não param de chegar receitas caseiras para curar as pessoas do coronavírus, e os remédios vão desde gargarejo com limão e mel, passando por beber água tônica e chega até a ingestão de água sanitária diluída em álcool.

O adjetivo "pós-verdade" tem sido recorrente para qualificar o cenário acima descrito. A origem deste termo é atribuída ao dramaturgo e romancista Steve Tesich que, no ano de 1992, escreveu um artigo intitulado "O governo de mentiras" (EL-JAICK, 2019). Analisando a conjuntura dos EUA, o autor do artigo aponta que os governantes mentiam para o povo estadunidense e não tinham a menor intenção de disfarçar tais mentiras (EL-JAICK, 2019; TESICH, 1992). O que Tesich discute no texto é que independente de saber se a informação era verdade ou mentira, a vida da população simplesmente seguia sem muito impacto. A pós-verdade seria uma espécie de indiferença diante dos fatos.

Em novembro de 2016, o Dicionário Oxford escolheu a "pós-verdade" como a palavra do ano e, de certo modo, mantém o significado trazido por Tesich: "circunstâncias em que fatos objetivos são menos influentes em formar a opinião pública do que os apelos à emoção e a crença pessoal" (D’ANCONA, 2018, p. 20). Como nos diz Mcintyre (2018), o prefixo pós assume não um sentido temporal (pós-pandemia ou pós-guerra), mas um sentindo de "deixada para trás, irrelevante". Sendo assim, esse termo carregaria a ideia de que, a verdade, se ela existisse, seria irrelevante.

A pós verdade carregaria, assim, pela definição do Oxford, um caráter priorizador do sentimento, da crença e um descrédito à razão, aos fatos e à própria noção de verdade. Não nos parece que tamanha irracionalidade, principalmente relacionada ao negacionismo da ciência e da ação política transformadora da realidade social, seja um puro acaso do momento político-econômico em que vivemos, no qual o capital penetrou em quase todos os espaços geográficos atuais, nas diversas culturas, na diversidade de indivíduos subjetivamente existentes.

As relações reprodutoras do capital se universalizaram e aqueles que não admitem que o capitalismo é o fim da história reconhecem a dificuldade, no plano prático-político, para transformar o atual estágio da humanidade, em que a barbárie já está instalada e a desumanização tem sido a tônica. Os velhos discursos fantasiados de modernos têm predominado em todos os cantos, inclusive na educação, no meio acadêmico e nas universidades. Através da ideologia neoliberal, que tem o mercado, com sua mão invisível, como fundante das relações sociais, a posição conservadora tem predominado. É preciso também reconhecer que, por outros caminhos e de uma forma mais complexa, as teses e

\footnotetext{
${ }^{3}$ Consulta feita no dia 27/05/2020.
} 
posturas pós-modernas ${ }^{4}$ têm ampliado e alimentado o debate, não necessariamente chegando, de forma direta, às mesmas teses conservadoras do mercado, porém diluindo ou negando o papel transformador dos sujeitos sociais, ainda mais daqueles que são obrigados a vender sua força de trabalho para sobreviver. Dessa forma, acabam também coadunando e reforçando as relações mercantis.

As teses pós-modernas decretaram a morte do sujeito, da razão, da história, das classes sociais e da possibilidade de o sujeito revolucionário transformar o mundo, nos diluindo nas diferenças (mais propriamente particularidades) culturais e nos diversos "discursos" possíveis sobre o mundo, negando a ciência estruturada a partir da modernidade e seu valor epistemológico, tornando a noção de verdade como mais um delírio da razão. Assim, a síntese pós-moderna se afirma e se sustenta no "fim das certezas" (LYOTARD, 1997) que, segundo eles, a modernidade com seu "iluminismo", muitas vezes de caráter totalitário, prometeu. Dessa forma, não há grandes narrativas, a modernidade se tornou uma grande ilusão (LYOTARD, 1997). Não por acaso, Mcintyre (2018) aponta a pós-modernidade como um dos fatores que conduziram à pós-verdade e para nós não é estranho que ideias que desdenham da razão, afloradas hoje no senso comum, já tenham aparecido nos teóricos da pós-modernidade, de maneira mais refinada, claro.

Então, é neste cenário conservador e pós-moderno que penetra fortemente na educação e no ensino de ciências, em todos os níveis escolares, as propostas pedagógicas construtivistas e o lema do aprender a aprender com seus corolários: o professor reflexivo, o professor pesquisador, o aluno aprendente, a pedagogia das competências e multiculturais, dentre outras (DUARTE, 2001; 2005). Aqui no Brasil, a Lei de Diretrizes Básicas da Educação (LDB), promulgada em 1996, é um reflexo desse cenário e influenciou as reformas curriculares, as novas formas de gestão e organização do ensino, da infância à universidade.

Assim, não por acaso, as pedagogias do aprender a aprender e suas correlatas surgem concomitantemente com as teses pós-modernas, lastreadas pela sua base material dada na reprodução do capital, agora em crise permanente, na sua nova dinâmica de acumulação e concentração proveniente da restruturação produtiva que tem como princípio estruturador a eletrônica em contraposição à eletromecânica. Todos esses movimentos têm como tempo histórico da sua sedimentação, guardada as devidas particularidades e intensidades temporais e geográficas, o final da década de 1960 e início da de 1970, momento importante para compreendermos a crise estrutural do capital.

$\mathrm{O}$ absoluto nunca deveria ter sido absolutizado, pois, numa perspectiva de conhecimento crítico-dialética, o absoluto só pode ser absoluto em relação a um campo de totalidade social histórica, que o relativiza no que se refere à totalidade posta em movimento; e, sendo assim, põe em movimento os dois polos: absoluto e relativo, sempre a partir da realidade material objetiva, que tem na problemática do conhecimento o objeto como

\footnotetext{
${ }^{4}$ Não negligenciamos e reconhecemos a complexidade e a variedade de posições que estão por trás do termo pós-moderno.
} 
prevalente na relação sujeito e objeto. Sendo assim, a crítica a determinadas perspectivas modernas que absolutizaram o conhecimento, a realidade objetiva e a ciência moderna é pertinente. Entretanto, o que estamos constatando, com as críticas pós-modernas, é que passamos agora da absolutização do absoluto para a absolutização do relativo, da absolutização do universal para a absolutização do singular.

É neste contexto sócio-histórico, de crise estrutural do capital, que a noção de verdade, erigida desde a antiguidade e posta atualmente na sua base moderna, tem sido negada. Por isso, pretendemos nesse artigo discutir princípios filosóficos, históricos e educacionais que possam contribuir para a formação de professores e o ensino de ciências na perspectiva histórico-crítica (sócio-histórica), recuperando a noção de verdade em chave crítico-dialética, na qual a razão ontológica se contrapõe à razão fenomênica.

Optamos neste texto fazer uma exposição com mais detalhes de aspectos que, de partida, parecem não ter relação imediata com o tema, mas que são imprescindíveis para o entendimento das discussões que fazemos. Os conceitos centrais do marxismo não são familiares para a maioria dos professores do ensino de ciências, e para que os nossas críticas e proposições sejam bem entendidas é preciso "limpar o terreno", com o intuito de fazer um debate franco e apresentar considerações que julgamos importante para entendermos o que chamamos de verdade e suas implicações para o ensino e para a prática do professor.

Desse modo, o texto está divido, além dessa introdução em outras quatro partes. $\mathrm{Na}$ primeira, vamos tratar de forma sintética o que é o ser social para o marxismo, como ele se forma, tentando evidenciar para os leitores porque a categoria trabalho é tão essencial para entendermos a categoria verdade. Na segunda parte, a partir do trabalho, avançaremos para a discussão da prática como critério de verdade no materialismo histórico-dialético, trazendo, nesse aspecto, os conceitos de razão fenomênica e razão ontológica, mostrando as relações com o desenvolvimento da ciência moderna. Na terceira, passamos a discutir especificamente o ensino de ciências, mostrando como perspectivas pós-modernas tem abdicado de disputar a concepção de mundo dos estudantes contribuindo para o cenário da pós-verdade e para a manutenção do capital. Por fim, concluiremos retomando o debate inicial, apontando o papel da escola neste cenário e advogando que a saída não se dará pela via da pós-modernidade, que longe de ser revolucionária é mais fruto do reflexo ativo material da crise estrutural do capital.

\section{A ontologia do ser social: por que insistir tanto na categoria trabalho?}

Junto com outros autores do campo marxista, a exemplo de Sergio Lessa e Ivo Tonet (2011), entendemos que as obras de Marx, situadas historicamente, com seu núcleo estruturante dado na ontologia do ser social, tendo a categoria trabalho como elemento central para entender a gênese (natureza genética-ontológica) e desenvolvimento do ser social - atualizada nas questões contemporâneas por outros autores marxistas -, é condição fundamental para compreender e explicar a crise atual pela qual a humanidade passa e seus possíveis desdobramentos. Dessa forma, o trabalho se configura como um instrumento teórico 
e prático para a luta revolucionária de transformação social, visando a emancipação humana. Compreendemos, ainda, que a filosofia, com sua dimensão política e sem reduzi-la a política, está desafiada hoje a dar conta dos problemas sociais que afligem a humanidade, pois "Não existem filosofias neutras, ou seja, filosofias que ignorem os dilemas históricos cruciais que a humanidade enfrenta" (LESSA; TONET, 2011, p. 12).

Sendo assim, a ontologia ou "materialismo novo" (de novo tipo comparado, principalmente, com Feuerbach (1804-1872) e com os antigos e medievos) instaurada por Marx, com grande contribuição de Engels e, posteriormente, já no início do século XX, com novas contribuições de Lenin, tem como ato filosófico basilar a retomada da perspectiva do "ser", com ênfase no "ser" social. Não podemos esquecer que Marx é um ser situado - no seu tempo histórico -, no qual as ideias sobre o movimento e a evolução do Universo, da terra, da vida e da constituição das espécies, culminando no ser social - um ser no mundo -, estruturadas gradativamente, vai influenciá-lo de forma determinante; assim como a filosofia hegeliana e a ação dos homens para transformar o mundo, tendo como fato emblemático a revolução francesa.

Para Marx, imerso nesse mundo em movimento e em transformação material objetiva - surgimento da sociedade burguesa -, passa a não fazer sentido a pergunta pela gênese do universo.

Nesse contexto, a questão da gênese foi se colocando com um problema premente. De onde vem o universo? Como surgiu a vida? Como nasceram as sociedades humanas? Estas e outras investigações apenas se tornaram possiveis na medida em que foi se afirmando a descoberta da historicidade ser uma categoria universal, isto é, de que tudo que existe tem uma história, é um processo (LESSA, 2019, p. 2).

Quando Marx (2005), nos Manuscritos Econômicos e Filosóficos de Paris, se referiu à ciência da geogenia, que deu um duro golpe na teoria da criação e levantou a questão da regressão infinita sobre a origem do primeiro homem e da natureza como um todo, ele estava mostrando que essas questões não são abstrações razoáveis:

Se você indaga acerca da criação da natureza e do homem, você está abstraindo estes. Você os supõe não-existentes e quer que eu demonstre que eles existem. Replico: desista de sua abstração e ao mesmo tempo você abandonará sua pergunta [...] Você pode retrucar: não quero conceber a inexistência da natureza, etc.; só lhe pergunto acerca do ato de criação dela, tal como indago ao anatomista sobre a formação dos ossos, etc. Como, no entanto, para o socialista, o conjunto do que se chama história mundial nada mais é que a criação do homem pelo trabalho humano, e a emergência da natureza para o homem, ele, portanto, tem a prova evidente e irrefutável de sua autocriação, de suas origens (MARX, 2005, p. 1).

Desse modo, o que Marx apresentava era o salto ontológico do ser orgânico para o ser social. É bom que se afirme que o ser orgânico é caracterizado pelo surgimento da vida e 
por sua determinação biológica, proveniente de outro salto ontológico: do ser inorgânico - a matéria inanimada - para a vida. Para Marx, falar do primeiro ser humano é impossível, já que se concebe a humanidade como se originando do desenvolvimento de espécies menos complexas. Não existe o primeiro homem, mas, sim, grupos de primatas que se desenvolveram até dar na ruptura ontológica, com o surgimento do trabalho consciente, que levou ao ser social ${ }^{5}$.

E continua Marx:

[...] Uma vez que a essência do homem, se tenha tornado evidente na prática, na existência sensorial, a busca de um ser estranho, um ser acima do homem e da natureza (busca que é uma confissão da irrealidade do homem e da natureza) tornase praticamente impossivel. $O$ ateísmo, como negação desse irrealismo, não mais faz sentido, pois ele é uma negação de Deus e procura afirmar, por essa negação, a existência do homem. O socialismo dispensa esse método assim tão circundante; ele parte da percepção teórica e prática sensorial do homem e da natureza como seres essenciais. É autoconsciência positiva humana, não mais uma autoconsciência alcançada graças à negação da religião; exatamente como a vida real do homem é positiva e não mais alcançada graças à negação da propriedade privada, por meio do comunismo (...) o comunismo é a forma necessária e o princípio dinâmico do futuro imediato, mas o comunismo não é em si a meta da evolução humana - a forma da sociedade humana (MARX, 2005, p. 1).

Assim, para ele, a essência humana tem que ser buscada na prática, na prática que transforma a materialidade objetiva, existentes nas relações sociais, na realidade, na materialidade terrestre e não no céu.

O ser social faz parte do Universo e tem como pedestal a matéria inorgânica e a vida/matéria orgânica, se constituindo, por superação a ambas, um ser de maior complexidade e se tornando um ser material que transforma o mundo material - natural e social permanentemente pela prática, tendo o trabalho de transformação da Natureza, a experimentação e a ação política como modalidades de práticas materiais transformativas (BARATA-MOURA, 1978). O trabalho, então, é um ato primário que precisa ser realizado diuturnamente para garantir a reprodução do ser social e a da espécie, e indo além, produza sua existência universalmente.

Assim, o ser social precisa o tempo todo mediar com a Natureza e com os outros seres humanos para garantir a vida. Condição essa que o impele a agir transformando a realidade objetiva, produzindo objetivações resultantes de um projeto idealizado na consciência, que, ao se concretizar (prática material transformativa) na materialidade do "ser" Natureza ou no "ser" social (Natureza na forma humana), produz um novo objeto existente

\footnotetext{
5 Essas rupturas não se explicam de forma dedutível e seu conhecimento continua em aberto pela ciência. Entretanto, isso não elimina o seu caráter de existência e verdade, essas rupturas são constatações ontológicas.
} 
fora da consciência, que passa a fazer parte dos processos causais existentes na realidade objetiva (LESSA, 2019).

Esses objetos, por sua vez, podem ser de duas ordens. Podem ser objetos resultantes do trabalho, isto é, podem ser a matéria natural transformada para atender às necessidades humanas. Ou podem ser objetos puramente sociais, isto é, que não envolvem qualquer transformação da natureza. São objetos que correspondem às relações sociais que os seres humanos estabelecem coletivamente entre si: pensemos em complexos sociais como o Direito, o Estado, a moral, a ética, o amor, as obras de arte e assim por diante. Os dois objetos são existentes, o que os diferencia é que, para transformar a natureza, o ser humano se defronta com uma matéria em que não opera a consciência, enquanto que, ao transformar as relações sociais, a matéria social, nos defrontamos com uma matéria que apenas pode existir pela mediação da consciência. E isso faz uma enorme diferença na vida cotidiana, ainda que nem sempre nos apercebamos dela (LESSA, 2019, p. 14).

Isso constitui a realidade social em cada contexto sócio-histórico e tem implicações na concepção de desenvolvimento social aqui tratado, o qual tem como características: o aumento da natureza-social (a nossa $2^{\mathrm{a}}$ natureza) sobre a natureza-natural (a nossa $1^{\mathrm{a}}$ natureza), a diminuição do trabalho socialmente necessário para a reprodução humana e a diminuição das comunidades autenticamente autônomas (LUKÁCS, 2010; LESSA, 2019).

$\mathrm{O}$ aumento da natureza-social significa que o ser social (Natureza-humana), a partir da sua gênese aos dias de hoje, cria, cada vez mais, ambientes materialmente existentes, seja transformando a natureza propriamente dita, na qual os processos inorgânicos e orgânicos dominam, seja na natureza humana, na qual a consciência é materialmente existente. É bom que se diga: a Natureza-humana (a Natureza no seu formato humano) é o ponto de partida e o limite daquilo que está socialmente posto. Em suma, a reprodução humana é um permanente processo de transformação da Natureza-humana com transformação também da naturezanatural, com a consequente alteração da paisagem terrestre. Ao fazer história, o ser humano vai imprimindo a sua marca na natureza-natural e na Sociedade, transformando ambas em Natureza-humana.

A diminuição do trabalho socialmente necessário para a reprodução humana tem como base a história do desenvolvimento das forças produtivas. Tal desenvolvimento aumenta a riqueza social e, em tese, a possibilidade de diminuir o trabalho socialmente necessário. Em termos de sobrevivência, no início da história social do homem - o homem primitivo -, tínhamos uma situação de extrema carência material para cada indivíduo e para o grupo social em que ele vivia, devido ao baixo desenvolvimento das forças produtivas (MORADILLO, 2010).

Chegamos a uma situação, pós-revolução industrial, na qual a possibilidade de suprir as necessidades dos indivíduos e de todo o grupo social aparece. Atualmente, temos a possibilidade de trabalharmos algumas horas por dia e de cultivarmos o tempo livre para 
apropriação e ampliação das criações humanas: o reino da liberdade está potencialmente posto para todos. Pela primeira vez na história da humanidade, dois fatores se superpõem para potencializar a superação do puro reino da necessidade para o reino da liberdade: o homem compreender que ele se faz homem a partir dele mesmo e a produção da "riqueza" social suficiente para atender todos os seres humanos. Em suma, a reprodução humana, por meio e através da prática material transformativa, potencializa a superação das carências individuais e sociais, abrindo espaço para o desenvolvimento do reino da liberdade (MORADILLO, 2010).

A diminuição das comunidades autenticamente autônomas tem como base a condução das interações entre grupos humanos com desenvolvimentos culturais diferentes de forma tendencial, ocasionando uma unidade entre elas. Unidade que se dá entre as várias possibilidades dadas pelos dois extremos culturais possíveis, no qual o desenvolvimento das forças produtivas joga papel decisivo. Em determinadas circunstâncias, o domínio de uma cultura sobre a outra pode se dar de forma radical, levando ao aniquilamento da cultura dominada. Neste caso, a unidade não se efetiva ou acontece com baixíssima contribuição da cultura exterminada. O fato é que, cada vez mais, devido ao desenvolvimento social e, consequentemente, à comunicação e interação entre todos os espaços geográficos da superfície da terra, diminui a possibilidade de existir comunidades isoladas (são poucas comunidades isoladas existentes). Efetivamente, estamos nos transformando em uma verdadeira "aldeia global". Dessa forma, o desenvolvimento humano abre espaço para o surgimento de uma autêntica comunidade humana baseada em uma cultura universal. Entretanto, nas condições atuais, essa "aldeia global" tem como principal mediador o capital forma alienada e alienante da existência humana - e não o pleno desenvolvimento do ser social, criando barreiras para a emancipação humana (MORADILLO, 2010).

Ao tomarmos o trabalho como categoria fundante do ser social e produtor da riqueza humana, fica clara a razão pela qual o materialismo histórico-dialético insiste tanto na discussão de classe, que muitos críticos colocam como ultrapassada. A classe para o materialismo histórico-dialético não assume a ideia de que devemos dividir a população pelos estratos econômicos (A, B, C e D) ou algo parecido. De acordo com o materialismo históricodialético, para pensarmos em classe, na sua essência, precisamos saber como a riqueza do mundo vem sendo produzida historicamente e no tempo histórico em que vivemos; na atualidade, a produção dessa riqueza se dá predominantemente numa relação em que sujeitos precisam vender sua força de trabalho (classe trabalhadora) a aqueles que vivem do trabalho explorado, pois são donos do meio de produção (burguesia). A nossa organização em classe está diretamente relacionada à forma pela qual produzimos e reproduzimos a nossa existência. Como nos diz Marx e Engels:

Em relação aos alemães, que se consideram isentos de pressupostos
[Voraussetungslosen], devemos começar por constatar o primeiro pressuposto de
toda a existência humana e também, portanto, de toda a história, a saber, o 
pressuposto de que os homens têm de estar em condições de viver para poder "fazer história”. a Mas, para viver, precisa-se, antes de tudo, de comida, bebida, moradia, vestimenta e algumas coisas mais. O primeiro ato histórico é, pois, a produção dos meios para a satisfação dessas necessidades, a produção da própria vida material, e este é, sem dúvida, um ato histórico, uma condição fundamental de toda a história, que ainda hoje, assim como há milênios, tem de ser cumprida diariamente, a cada hora, simplesmente para manter os homens vivos. Mesmo que o mundo sensível, como em São Bruno, seja reduzido a um cajado, a um mínimo, ele pressupõe a atividade de produção desse cajado. A primeira coisa a fazer em qualquer concepção histórica é, portanto, observar esse fato fundamental em toda a sua signifcação e em todo o seu alcance e a ele fazer justiça (MARX; ENGELS, 2007, p. 32-33).

Portanto, por mais óbvio que pareça, o princípio básico para reproduzirmos nossa vida é estar vivo. E, nesta sociedade, a nossa forma de viver (ou não viver) se dá orientada pela mercantilização, que é comumente normalizada e naturalizada pelo capitalismo. Quando o materialismo histórico-dialético está falando de trabalho e classe, não o faz por preferência branca eurocentrada, o faz porque discutir o modo como produzimos e reproduzimos a vida material e ideal é essencial, entretanto, não suficiente para debatermos, inclusive, as diversas formas de opressão.

Daí, como nos mostra Samora Machel, líder revolucionário moçambicano do século $\mathrm{XX}$, não basta substituir os atores da política buscando mais representatividade se o horizonte de classe continua sendo o mesmo, se o modo como produzimos e reproduzimos nossa existência continua o mesmo.

É necessário conhecer claramente estes pontos. Há nacionalistas, uns ingenuamente por não possuírem uma consciência de classe desenvolvida, outros porque estão comprometidos com a exploração, que pensam que o objetivo da nossa luta deveria ser a de instalar um Poder negro, em vez dum Poder branco, nomear ou eleger africanos para os diferentes postos políticos, administrativos, econômicos e outros, que são hoje ocupados por brancos. (...) A nossa luta, para eles, deveria ser uma luta entre o Poder negro e o Poder branco, quando para nós a luta é entre o Poder dos exploradores e o Poder Popular (MACHEL, 1974, p. 24).

O modo de produção e reprodução da nossa existência tem direta relação com a forma que conhecemos o mundo e as necessidades postas que foram aparecendo no decorrer da nossa história e como fomos concebendo o conceito de verdade e de produção do conhecimento. Nos debruçaremos sobre esses aspectos na próxima seção. 


\section{A prática social como critério de verdade no materialismo histórico-dialético: uma discussão a partir do fundamento da categoria trabalho}

Somos seres historicamente configurados - fazemos parte da história universal - e ontologicamente ativos; produzimos a nossa existência para além daquilo que o mundo natural disponibiliza e, por isso, precisamos nos relacionar com a Natureza, através do trabalho, e com os outros seres humanos, para sobrevivermos e reproduzirmos a vida, afastando as barreiras naturais e produzindo conhecimento. “A condição humana (social) é a de seres mergulhados num mundo - natural e social - possuidor de uma realidade objectiva bem determinada" (BARATA-MOURA, 1978, p. 77).

O materialismo histórico-dialético assenta na prática o seu critério de verdade. No entanto, é preciso caracterizar esse conceito. A prática que vamos tratar, a partir, principalmente, de Barata-Moura (1978; 1994), e no seu sentido "forte" - para além dos seus vários significados e sentidos possíveis -, vai estar associada à atividade material de transformação, “ontologia e destinação de humanidade" (BARATA-MOURA, 1994, p. 19). Por isso, a prática que vamos nos referir vai ser sempre aquela que requer e demanda um envolvimento e engajamento do ser social no experimentar, no trabalho com a Natureza e na ação política, atos intencionais que redundam em atividade material transformativa (natural e social), objetivamente elucidada (BARATA MOURA, 1978). A prática aqui, portanto, não está associada imediatamente a elementos individuais ou a comunidades locais, mas, sim, com a possibilidade de ação-transformação do ser social no mundo, sempre tendo por base a materialidade objetiva, natural e social existente. Uma prática modulada pelo "ser" da Natureza e da Natureza-humana

$\mathrm{O}$ agir humano, sobretudo na sua fase atual de desenvolvimento, requer sempre uma teoria - um conhecimento carregado de prática objetivada e coletivizada historicamente - que o informe e oriente, decerto. Contudo, analisando de forma dialética, deve ser uma teoria apropriada no processo, sintetizada a posteriori e impregnada com a historicidade do objeto (sempre imerso na totalidade material histórica do ser) ao qual ela se refere e que o ser social quer conhecer, além de ter na prática de transformação material do objeto o seu critério de verdade. A teoria, ao ser sintetizada (e retroalimentada) no processo prático de transformação material da realidade, tende a se estabilizar, criando condições para novas imersões na realidade objetiva em movimento.

A teoria pode ter força material, pois ela, por si só, não põe causalidade na realidade, mas, como é fruto da experiência humana acumulada, não está desprovida de interferir na realidade objetiva, entretanto, a prática é o momento decisivo. Estamos afirmando isso para não cairmos em determinadas perspectivas idealistas que afirmam "que o critério da verdade é interior à esfera da própria teoria” (BARATA-MOURA, 1978 p. 277). A relação complexa entre prática e teoria deve ser resolvida em termos de uma mediação social de caráter dialético, que lhe confere unidade, que tem a prática como polo determinante e depende de 
sua condição estrutural, tanto da natureza como na sociedade. "A praxis ${ }^{6}$ não pode ser reduzida à actividade da consciência humana” (BARATA-MOURA, 1978, p. 284).

A perspectiva de conhecimento numa abordagem crítico-dialética tem que considerar a objetividade, que é o fundamento material da realidade e da história, na sua totalidade e contradição; implicando na tese de que a:

\begin{abstract}
imposição e estatuto da própria realidade objectiva, a imanência do saber ao próprio real por que pergunta e do qual sempre se estabelece como reflexo (se bem que nem sempre inteiramente adequado) [...] Eles definem, de algum modo, os parâmetros dentro dos quais resulta possivel reflectir adequadamente o devir em que o real consiste.[...] um reflexo que se processa e determina ele próprio em termos históricos.[...] o problema da verdade sempre tenha de colocar-se nos termos de uma relação dialéctica entre o relativo e o absoluto, sob o fundo de uma sua determinação essencial que é a objectividade ou o fundamento material (BARATA-MOURA, 1978, p. 69-70).
\end{abstract}

Por isso, historicamente, temos observado que os conhecimentos de determinada época tendem a refletir a base material objetiva na qual eles se ergueram - a realidade objetiva -, nem sempre de forma mais fidedigna, contudo, dando sustentação às relações de reprodução material de existência das comunidades situadas, constituindo um determinado modo de produção da vida, conformando determinadas formas de pensar e agir - suas estruturas cognoscitivas historicamente determinadas -, implicando nas representações da realidade. Dessa forma, compondo aquilo que denominamos de "experiência", de "vivência" e de "saber" (BARATA-MOURA, 1978, p. 77).

Ao falarmos do conhecimento como reflexo da realidade não estamos defendendo uma cópia mecânica como querem crer alguns dos críticos do materialismo históricodialético. O movimento de apreensão da realidade pela via do pensamento é sempre um processo aproximativo (nem por isso irreal) em que as imagens são postas a prova pelo polo da prática no desenvolvimento histórico da humanidade.

O exercício que Marx nos coloca é sempre de entender que o conhecimento do real precisa sempre superar por incorporação a aparência. Aquilo que salta aos olhos, que se apresenta como fenômeno não necessariamente condiz àquilo que o objeto é em sua essência. Quando nos deparamos com o dinheiro, um metal, uma lâmpada, o livro, o que temos ali são características exteriores, de modo que conhecer o fenômeno passa por ir além daquilo que ele apresenta inicialmente. Não à toa, Marx (1980) defende que se a aparência do objeto coincidisse com a essência, a ciência seria supérflua.

\footnotetext{
${ }^{6}$ Barata-Moura, em sua obra Ideologia e Prática, cita e reproduz o conceito de Práxis de Heinrich Opitz, que é o seguinte: "O conceito marxista da praxis relaciona-se com o conjunto do processo social, no qual a humanidade transforma a realidade objectiva. A praxis é o processo de vida material da sociedade, em que a humanidade permanentemente se mantém e desenvolve. À praxis pertencem, por exemplo, a produção, o trabalho, assim como a luta de classes, a actividade política, a formação de condições de vida e de trabalho socialistas e outras atividades" (BARATA-MOURA, 1978, p. 252)
} 
Cabe à ciência, portanto, encontrar reflexos cada vez mais adequados do real para que o ser humano possa chegar, pela via do pensamento, ao concreto que já existe no real objetivo (materialmente determinado).

O subjetivo é sempre uma estrutura ideal do conhecimento, enquanto a verdade está relacionada "[à] adequação do conhecimento com a realidade objectiva" (BARATAMOURA, 1978, p. 75).

O pensamento verdadeiro é subjectivo, no que respeita à sua forma ou modo necessário de estruturação, e objectivo no que respeita à sua matéria. O conhecimento remete sempre para as formas «ideais» (subjectivas) por que e em que reflecte a realidade objectiva. Estas imagens cognoscitivas, indispensáveis à determinação de um qualquer conhecimento, reflectem, porém - ao nivel e segundo as formas que the são próprias -, a materialidade do objeto (BARATA-MOURA, 1978, p. 74).

O verdadeiro se contrapõe ao subjetivismo, que ao idealizar o objeto, inverte a relação, dando prioridade ao sujeito e dando autonomia absoluta aos elementos subjetivos "construídos". Construídos a partir dos dados empíricos e "colados" neles, não ultrapassando, se contentando com os dados singulares, cabendo ao sujeito do conhecimento transformar esses dados em totalidade organizada, ao seu sabor e talento. Instituindo a realidade.

Por isso, Marx (1980) parte sempre do empírico, do fenômeno, daquilo que aparece, da factualidade, do fenomênico. Para isso, utiliza uma visão binocular, um olho na observação direta e o outro na observação indireta (NETTO, 2008). Procura o movimento sincrônico e diacrônico do objeto. Na observação direta, procura capturar as relações recíprocas e determinações, só que, como a gênese não se confunde com o desenvolvimento e com a estrutura, essa observação direta teria pouco poder heurístico, já que não faria emergir o significado do objeto. Por esse motivo, ele precisa da observação indireta, para, na diacronia, capturar a gênese. É sempre uma análise categorial e histórica. $\mathrm{Na}$ procura pelas simultaneidades e sucessividades, ele encontra processos, onde o ser precisamente-assim se expressa (NETTO, 2008).

Segundo Netto (2008), "Marx opera a velha tradição filosófica ocidental, posta hoje em questão pelos pós-modernos, da distinção entre aparência e a essência" e continua:

Segundo Marx, para captar a aparência, para sinalizar o conjunto de processos de um fenômeno não é necessário nenhuma pesquisa. Basta mirá-la, basta verificá-la, basta constatá-la. Em Marx, a aparência não é descartada, não é secundarizada, mas ela tanto revela quanto oculta a essência. Donde, partir da aparência significa partir da factualidade para localizar processos que remetem a novos dados, que remetem a novos processos e que, portanto, permite, numa viagem regressiva, num caminho de volta, retomar aquela mesma factualidade que foi o ponto de partida inicial e encontrar nela, retirando da sua processualidade, os traços que a particularizam (NETTO, 2008, p. 80-81). 
Para Marx, a busca dessas regularidades expressa tendências, são as chamadas leis empíricas, expressão da ciência da sua época que ele também utiliza (NETTO, 2008). Nesse processo, não há identidade sujeito-objeto e o sujeito não se afasta do objeto, ao contrário, quer conhecê-lo por aquilo que é a expressão da práxis da sua época: tornar esse desconhecido como partícipe do conhecido, isto é, incorporá-lo à totalidade existente naquele momento histórico, torná-lo parte de uma totalidade. Nesse exato sentido, não há neutralidade do sujeito: atividade prática, teórica e valorativa se tornam indissociáveis, contudo, o momento predominante está na prática material que transforma uma forma específica de atividade humana.

O conceito de totalidade que aparece no marxismo é algo que vale a pena ser discutido aqui. Ao conhecer, o ser humano jamais esgota a realidade, visto que ela está sempre em movimento ${ }^{7}$ e há sempre outras determinações não apreendidas, no entanto o que conhecemos da realidade não são fragmentos isolados sem conexão e sem base material.

(..) totalidade não significa todos os fatos. Totalidade significa: realidade como um todo estruturado, dialético, no qual ou do qual um fato qualquer (classe de fatos, conjunto de fatos) pode vir a ser racionalmente compreendido. Acumular todos os fatos não significa ainda conhecer a realidade; e todos os fatos (reunidos em seu conjunto) não constituem, ainda, a totalidade. Os fatos são conhecimento da realidade se são compreendidos como fatos de um todo dialético (..) se são entendidos como partes estruturais do todo. (...) Sem a compreensão de que a realidade é totalidade concreta - que se transforma em estrutura significativa para cada fato ou conjunto de fatos - o conhecimento da realidade concreta não passa de mística, ou a coisa incognoscivel em si (KOSIK, 1976, p. 35-36).

Em síntese, o concreto, a realidade objetiva, é sempre o ponto de partida do conhecimento (como também de chegada), que colado na experiência empírica, imediata, reflexo do processo histórico que se encontra naquele momento, com uma determinada configuração relacional, total e contraditória, aparentemente fixa e regular, imutável, precisa ir além, para apanhar a realidade objetiva no seu devenir, no seu movimento, precisando, para isso, fazer um "desvio" abstrativo, com o objetivo de decompor o real em seus momentos causais, naturais e sociais, para, em seguida, ter uma compreensão da realidade objetiva na sua integralidade, agora como concreto pensado (ponto de chegada e de partida para novos processos). Portanto, metodologicamente, a realidade objetiva precisa ser apurada, já que a forma com que ela se apresenta de imediato, nas suas partes e como totalidade, só se oferece à consciência nas suas formas fenomênicas (MARX, 1996).

Esse conhecer da realidade objetiva do ser humano não está solto no ar. A fidelidade ou as distorções do real objetivo dependem do movimento histórico e das possibilidades

\footnotetext{
${ }^{8}$ A natureza, a sociedade e o pensamento estão em movimento, com dinâmicas diferentes, na qual o ser mais complexo, o ser social com sua consciência e sua atividade pensante - a subjetividade -, pode se apropriar dessa totalidade, pois vive imerso nessas dinâmicas. Uma totalidade aberta, histórica e materialmente determinada.
} 
históricas que a humanidade tem de acessar esse real e os interesses que se apresentam no movimento de acesso ou não dessa realidade.

Na transição para idade moderna, no mundo ocidental, por exemplo, a burguesia foi revolucionária e seu agir prático transformou materialmente a realidade objetiva, negando o modo de vida feudal e transformando de forma radical os meios de produção da nossa existência, seja no modo de produzir bens materiais, no qual a economia política é o seu fundamento; seja no modo de produzir conhecimento, no qual as questões epistemológicas e ontológicas são determinantes; ou ainda, no modo de produzir valores sociais, com suas demandas políticas e éticas; três dimensões fundamentais da nossa existência.

Com relação às mudanças no modo de produzir conhecimento, podemos dizer que do mundo grego ao medievo, passando por Sócrates a São Tomás de Aquino, com suas especificidades e diferenças, o problema que se põe ao conhecimento é sempre precedido de uma questão filosófica maior: o que é o "ser", do "ser" enquanto "ser", da ontologia no seu sentido amplo - lato sensu. Na relação sujeito/objeto, o objeto precede (a realidade objetiva), é o polo determinante. O conhecer estava subordinado ao "ser", dentro de uma perspectiva metafísica, que variou de configurações e matizes. Um "ser" de essência fixa e imutável, seja em chave materialista ou idealista (ANDERY et al., 1995; LESSA, 2019; TONET, 2010).

$\mathrm{Na}$ modernidade ocidental, a possibilidade do conhecimento do "ser" será questionada, colocada em "suspensão", proporcionando um outro empreendimento com relação ao problema do conhecimento, no qual o centro de gravidade sai do "ser" para o sujeito que conhece, para a centralidade da subjetividade. O progresso e sucesso das ciências da natureza do final do século XV ao início do século XIX (com outros grandes momentos posteriores, pós sedimentação das bases modernas) vai ter uma forte influência nessa forma de pensar, já que emerge uma nova concepção de natureza e de ciência e essa passa a se constituir como um campo de conhecimento autônomo (uma autonomia relativa), se separando da filosofia.

Nas ciências da natureza, com mais propriedade iniciando pela física, a concepção de causalidade muda, saindo de uma concepção predominantemente aristotélica de caráter orgânico, no qual agente, paciente e efeito (concepção ternária) se entrelaçam, para uma concepção binária e mecânica, envolvendo causa e efeito (ABRANTES, 1988). Uma natureza desencantada e desantropomorfizada aparece, e contém regularidades possíveis de serem descritas por algoritmos matemáticos (relações e quantidade são estabelecidas), já que, como bem postulou Galileu Galilei (1564-1642), a natureza foi escrita com caracteres matemáticos (GALILEI, 1987). Sendo assim, posso manipular os objetos da natureza nos seus momentos fenomênicos e estabelecer relações matemáticas, são as chamadas leis da natureza.

Assim, o acesso ao "ser" como uma proposição metafísica fica secundarizada e o sujeito passa a ter a primazia no processo do conhecimento, passa a ser o eixo de onde o objeto é configurado e estruturado, culminando na síntese de Kant (1724-1804) na filosofia, a chamada virada copernicana na filosofia (sai da centralidade do objeto para o sujeito), que, 
através do seu criticismo transcendental, vai afirmar que não podemos conhecer a coisa em-si - o númeno -, já que só temos acesso ao fenômeno, a coisa para mim. $\mathrm{O}$ acesso à essência do "ser" fica interditado e a filosofia se reduz, praticamente, a uma teoria do conhecimento, a uma epistemologia (ANDERY et al., 1995; TONET, 2010; LESSA, 2019).

O kantismo é considerado uma síntese empírica/racional, envolvendo sensibilidade e entendimento, que tem como premissa maior, como dito antes, que não posso conhecer a coisa em-si, conheço apenas o que os órgãos da minha sensibilidade apanha dos fenômenos, usando como "instrumentos" as formas da sensibilidade, preexistente no sujeito - na intuição -, do espaço e tempo; junto com as categorias a priori, dada no intelecto, da quantidade, qualidade, relação e modalidade, que criam as representações provenientes da intuição sensível, sintetizam o múltiplo originado da intuição. Dessa forma, modulando os fenômenos, dando objetividade (TONET, 2010; OLIVEIRA, 2001).

Daí porque a razão fenomênica tem na subjetividade o seu polo regente. É ela quem ordena o mundo; é ela quem, partindo dos dados empíricos, mas sem ultrapassálos, confere uma lógica ao mundo (TONET, 2010, p. 6).

Com isso, a razão fenomênica ganha destaque, com suas implicações nos séculos posteriores e na atualidade (fenomenologia, existencialismo, pragmatismo, filosofia analítica, por exemplo). A teoria kantiana sofreu críticas e reformulações, entretanto, o seu núcleo central, no qual as operações do sujeito com os dados empíricos provenientes dos fenômenos são os fundamentos do conhecimento científico, continuou sendo, até hoje, determinante no método científico (TONET, 2010).

Aqui vale a pena salientar que as influências de Kant foram múltiplas, as novas gerações de filósofos, concordando ou não com ele, transitaram pelas suas formulações. Da primeira para e segunda metade do século XIX, Augusto Comte (1798-1857) vai afirmar que não precisamos saber o que são as coisas (a questão ontológica é secundária, considerada uma proposição Metafísica), mas, sim, como as coisas funcionam (a questão epistemológica precede), estava lançada a premissa maior do positivismo comtiano, com suas implicações na "física social", a sociologia. O sucesso das ciências da natureza vai influenciar fortemente as ciências sociais (ANDERY et al., 1995).

Marx (1818-1883) é quem vai restaurar a razão ontológica na modernidade, só que agora superando os gregos e medievos, pois a essência em vez de ser fixa e imutável também é histórica. Assim, fenômeno e essência são históricos, com importância no processo de conhecimento, no qual a essência retém a continuidade dos processos, enquanto o fenômeno está associado à descontinuidade dos processos. Marx rompe com a razão ontológica de caráter especulativa e funda uma razão ontológica de caráter materialista dialética, no qual "ser" e historicidade estão conjugados.

Marx lançou os fundamentos de Método Científico: uma abordagem ontológica, uma concepção radicalmente nova de mundo. E de que, com isto, também fundou 
uma concepção profundamente nova de produzir conhecimento científico e de articular filosofia e ciência. Também nos permitiu fundamentar a afirmação de que essa concepção de mundo e de conhecimento científico expressa a perspectiva da classe trabalhadora e está articulada com a superação radical do modo de produção capitalista e com a construção de uma forma de sociabilidade comunista - na qual esteja superada toda forma de exploração, de opressão e de dominação do homem pelo homem e na qual se abra a possibilidade de plena realização para todos os indivíduos (TONET, 2013, p. 127).

Essa nova forma posta por Marx não nega as conquistas científicas feitas pela ciência moderna, mesmo sustentadas pela razão fenomênica. Se o real existe e a prática transformativa é o critério de verdade, entendemos que muito do reflexo do real produzido pela sociedade burguesa, no que tange às ciências naturais, passa pelo crivo da prática transformativa e, portanto, é verdadeiro dentro dos seus limites históricos ${ }^{8}$. No entanto, estamos cientes que diante de um cenário ideológico que vivemos, muito dessa produção precisa ser superada e, hoje, está presente na ciência apenas para endossar os privilégios da classe dominante. A decadência ideológica burguesa está expressa na razão pós-moderna.

O pensamento pós-moderno, com toda a sua diversidade de posturas e temáticas, tem como uma das suas características negar as categorias da totalidade e da essência, assumindo, assim como a razão fenomênica faz, que os dados empíricos, na sua forma fenomênica se bastam, sendo o ponto de partida e de chegada do conhecimento, radicalizando nesta postura, pois nega categorias de universalidade, racionalidade, história, humanidade, progresso, objetividade, dentre outras, colocando a realidade sob indeterminação total ao fragmentá-la (MORAES, 1996; 2003; TONET, 2010). Na ciência, essa perspectiva do fim das certezas tem penetrado fortemente, relativizando, do ponto de vista axiológico, os conhecimentos considerados científicos e outras formas de conhecimento, a exemplo do conhecimento mágico, mítico, encantado e antropomorfizado, além da valorização dos conhecimentos regionais, locais, populares, que são considerados conhecimentos que não se "dobraram" ao conhecimento Ocidental, eurocêntrico e americanizado, por si só opressores e colonizadores. Entendemos que a ciência sempre lida com certezas históricas, provisórias, sendo a dúvida inerente a essa atividade. Nos campos social, político e econômico, o fim das certezas trouxe outro significado: eliminar a possibilidade da igualdade social substantiva, a possibilidade da emancipação humana (MÉSZÁROS, 2006). Para nós, essas incertezas têm que ser buscadas na sua materialidade, na sua historicidade, na práxis humana, nos atos transformativos pela prática social da realidade material objetiva. Temos que entendê-las nas contradições

\footnotetext{
8 As ciências naturais têm como núcleo onto-epistemológico uma concepção de natureza desencantada e desantropomorfizada, algo fundamental para uma concepção materialista da realidade, que mesmo com os desvios de uma razão fenomenológica, precisa sempre se acertar com a realidade objetiva. Os exemplos abundam na história das ciências da natureza. As controvérsias do atomismo durante todo o século XIX, com as correntes atomistas, antiatomistas e energeticistas, que culmina no início do século XX com as proposições de aceitação da realidade atômica a partir dos trabalhos de Jean Perrin (1870-1942), e com novos desdobramentos posteriores com a teoria quântica, é um bom exemplo (OKI, 2006; 2009).
} 
inerentes a essa forma histórica da humanidade se organizar para produzir e reproduzir a sua existência.

Considerar a forma que produzimos e reproduzimos nossa existência não torna 0 materialismo histórico-dialético eurocêntrico, economicista e que, portanto, deixaria de lado as questões relativas à (de)colonialidade, povos originários, questões de raça, questões de gênero etc. Embora existam marxistas que desconsideram essas pautas, não se trata de uma questão inerente ao marxismo. O materialismo histórico-dialético trabalha com a ideia de uma realidade que existe e é cognoscível, de modo que não existe classe trabalhadora no abstrato. Esse trabalhador tem raça, gênero, territorialidade e todas essas particularidades fazem parte do modo como esses sujeitos se relacionam para produzir a sua existência a partir do trabalho. Já há muita gente que produziu e muita gente produzindo literatura que mostra como essas pautas estão articuladas e fazem parte da totalidade, e estão presentes no marxismo desde a modernidade, e são essenciais para o debate e para uma compreensão de mundo que não aceita o que está posto (LANDI FAZZIO; MANOEL, 2019; HAIDER, 2019; DAVIS, 2016; SAFFIOTI, 1976)

O que nós, a partir do materialismo histórico-dialético, não fazemos é ceder à ideia de que qualquer grupo está longe da ideologia dominante e produz conhecimento revolucionário apenas pelo fato de ser oprimido pelo capitalismo. Assim como não entendemos que o conhecimento produzido na sociedade burguesa seja em si burguês e, por isso, falso e carregado da ideologia dominante. Fiquemos com a lição de Lênin:

Se não nos dermos perfeitamente conta de que só se pode criar essa cultura proletária conhecendo com exatidão a cultura criada pela humanidade em todo o seu desenvolvimento e transformando-a, se não atendermos a isto, nunca poderemos resolver semelhante problema. A cultura proletária não surge de fonte desconhecida, não brota do cérebro dos que se intitulam especialistas na matéria. Seria absurdo pensar assim. A cultura proletária tem de ser o desenvolvimento do conjunto de conhecimentos conquistados pela humanidade sob o jugo da sociedade capitalista, da sociedade dos latifundiários e burocratas (LENIN, 1977, p. 125).

O anúncio dessas questões é essencial para o debate que travaremos na próxima seção.

\section{O ensino de ciências que disputa a concepção de mundo: um contra-ataque à indiferença epistemológica e à rendição ao capitalismo}

Até aqui, foi possível estabelecer o que estamos chamando de ser social, conhecimento e totalidade dentro do materialismo histórico-dialético. Evidenciamos, ainda que rapidamente, como se deu o processo de conhecimento da humanidade tentando estabelecer uma análise onto-epistemológica do processo de produção do conhecimento da humanidade. Para um leitor não familiarizado com essas questões, entendemos que o texto 
possa ainda estar em um nível abstrato, mas tentaremos nesta seção dar mais concretude aos aspectos sinalizados, mostrando como esses conceitos são úteis para análise dos exemplares no ensino de ciências.

No cenário da pós-modernidade, aparecem exemplos de trabalhos da área de ensino de ciências (COBERN; LOVING, 2001; BAPTISTA, 2014; PAIVA; MARTINS; ALMEIDA, 2015) que consideram que o conhecimento científico é um tipo de conhecimento com validade restrita ao contexto, que deve dialogar, de modo horizontal, com os outros saberes, sem querer substituí-los. Com o objetivo de respeitar as diferenças culturais e superar o tal paradigma da modernidade, muitos pesquisadores e pesquisadoras assumem que o conhecimento científico na escola é apenas mais uma forma de ver o mundo, nem melhor, nem pior que outras, sendo apenas diferente. $\mathrm{O}$ argumento comumente usado é que quando a ciência é evocada como um conhecimento universalizante ela é doutrinadora e, necessariamente, opressora. Caberia, a priori, respeitar epistemologicamente, em si mesmo, os saberes e sabores diversos construídos pelo senso comum, pela igreja e outras manifestações religiosas, e pelas diversas epistemologias rejeitadas. Qualquer outra opção diferente dessa é considerada cientificista.

Não raro, também, para explicar que o conhecimento científico tem valor epistemológico diferente, e não superior aos outros saberes, se compara a ciência com a arte e ficção e faz-se o mesmo com a história que é equiparada com a literatura (MORAES, 2004). As fronteiras entre os objetivos da produção humana aparentemente desaparecem, restando apenas uma amalgama amorfa de conhecimento que é impossível de ser valorada, sendo apenas julgada a partir de um acordo da comunidade.

A ciência faz parte das humanidades. Enquanto narrativa não ficcional tem um grau de criatividade menor, mas, precisamente, é apenas uma questão de grau o que a distingue da ficção criativa. Nestas condições, está preludida qualquer possibilidade de demarcações rígidas entre disciplinas ou entre gêneros, entre ciências naturais, sociais e humanidades, entre arte e literatura, entre ciência e fiç̧ão (SANTOS, 2013, p. 348).

Desse modo, o que há são verdades estabelecidas pelos consensos comunitários. Ensinar ciência é só mais uma forma de ver o mundo, um óculos que o sujeito pode usar ou não a depender da situação em que ele esteja vivendo.

A maioria desses autores não desconsideram a existência da realidade e nem mesmo abandonam o conceito de verdade. Para essas perspectivas, a verdade assume um valor pragmático (COBERN, LOVING, 2001; COBERN, 1996). Nestes artigos, aparece a ideia de que o conhecimento científico deve ser ensinado na escola e até tem valor de verdade, no entanto, como trata-se de uma perspectiva relativista em sua raiz, advoga, de maneira coerente, que a escola não deve ter como objetivo mudar a "crença" do estudante sobre o que se está estudando, visto que seria doutrinação. Vejamos como isso é defendido por Teixeira (2016) quando trata do ensino da evolução: 
o objetivo do ensino de ciências deve ser o entendimento e não uma mudança de crença (COBERN, 1994; SMITH, SIEGEL, 2004; REISS, 2008; 2009). Assim, o ensino da teoria da evolução deve estar orientado para a sua compreensão enquanto teoria cientifica, construída a partir de evidências empíricas e de intensos e múltiplos estudos, sem que isto seja imposto como uma verdade absoluta ao estudante cujas crenças porventura podem entrar em choque com a visão da ciência (TEIXEIRA, 2016, p. 2097).

Embora as descrições do cenário acima tratem de abordagens diferentes, não contemplem a diversidade de posições do campo e tenham implicações diferentes para área, que até trazem contribuições para o ensino de ciências, elas se sustentam, intrinsecamente, dentro do mesmo campo ideológico burguês da doutrina da dupla verdade muito bem explicada por Lukács (2018).

$\mathrm{O}$ autor húngaro nos mostra que com o florescimento do Renascimento e com as descobertas de Kepler, Copérnico e Galileu, a base ontológica do geocentrismo estava abalada. Inicialmente, essas e outras descobertas puderam até ser tratadas como heresia, castigando, de diferentes formas, os sujeitos que a propuseram. No entanto, Lukács nos mostra que, neste período de explosão de crises das bases econômicas e ideológicas, a Igreja ainda recorre a um outro recurso para resistir, temporariamente, àquilo que abalaria o pilar na sua estrutura ontológica (onipotência divina que faz de Deus criador da Terra como centro do universo, o caráter teleológico do cosmo): a dupla verdade. A recorrência a essa doutrina é comumente associada ao nome do Cardeal Belarmino, e vamos agora ao próprio Lukacs para explicar o que ela vem a ser:

Brecht, em seu drama sobre Galileu, faz o cardeal Belarmino expor de maneira cínica e clara a nova versão da dupla verdade: "Vamos nos adequar aos tempos Barberini. Quando novas cartas astronômicas, baseadas em novas hipóteses, facilitarem a navegação de novos marinheiros, eles devem usá-las. A nós desagradam apenas as teorias que falsificam a Escritura" Do ponto de vista da honestidade no desejo de conhecer a realidade, a dupla verdade sempre teve em si qualquer coisa de postura cínica. Tal caráter ainda se reforça quando não se trata de obter um pouco de espaço para um conhecimento antes reprimido ou condenado à extinção, mas de, com sua ajuda, manter intacta no plano organizativo a validade oficial de uma ontologia. No entanto, esse cinismo expressa de maneira apropriada a percepção instintivamente correta da nova situação por parte da igreja: para a nova classe dominante em ascenção, para a burguesia, o desenvolvimento irrestrito das ciências, sobretudo das ciências naturais, era uma questão vital (LUKACS, 2018, p. 38-39).

Parece ter ficado claro o que as ideias de Belarmino representavam: o conhecimento científico deveria ser usado apenas na sua possibilidade de manipulação prática, mas não deveria ter o papel de perturbar as concepções de mundo trazidas, na época, pelas Escrituras. 
A recorrência à dupla verdade é requisito dos ideais dominantes que, no geral, precisam conservar valores ao mesmo tempo em que não podem abdicar da objetividade do real.

Como mostramos no tópico anterior, o desenvolvimento da sociedade burguesa permitiu o avanço das forças produtivas e das ciências, e, ao alçar ao status de classe dominante, a verdade passa a ser incômoda, já que a concepção de mundo desenvolvida historicamente por esse conhecimento, impede a sustentação dos elementos ontológicos da burguesia, rompendo com a ideologia que mantém as massas submissas. Como não pode ir até o final no debate sobre o conhecimento verdadeiro, a classe dominante cria ${ }^{9}$ um ambiente fértil, mais uma vez ${ }^{10}$, para a aceitação da dupla verdade. Essa ideia é levada às últimas consequências no século XX e, neste cenário, caberia à ciência uma preocupação com as questões práticas e de uso pragmático, olhando muito mais para como as coisas funcionam e como conhecemos as coisas do que efetivamente como elas são ${ }^{11 .}$ Nesse aspecto, caberia devolver à religião (ou religiões) o seu direito de determinar a ontologia. Desse modo, a estrutura ideologicamente decadente que se abre neste novo momento de reestruturação produtiva do capital no século XX leva ao extremo a dupla necessidade burguesa "de valorizar e utilizar ilimitadamente as descobertas da ciência na economia e na vida social etc., por um lado e, por outro, manter historicamente ativa nas massas uma necessidade religiosa, por mais esmaecida que seja" (LUKÀCS, 1998, p. 53). Assim, como nos diz Duarte (2016, p. 113):

\begin{abstract}
Disseminou-se, assim, a ideia de que a ciência deve abster-se de discussões envolvendo concepções de mundo, deixando o caminho aberto para o irracionalismo e o misticismo das religiões. A burguesia encontra, desta maneira, o caminho para fomentar o desenvolvimento científico, minimizando, ao mesmo tempo, as consequências negativas desse desenvolvimento para a manutenção da necessidade religiosa nas massas, já que tal necessidade é de expressiva ajuda na domesticação da classe dominada.
\end{abstract}

Entendemos que nas descrições que fizemos sobre as atuais tendências do ensino de ciências, fica evidente essa não tomada de posição diante da realidade e de uma sociedade burguesa desumanizadora. Sob a égide do discurso de respeito às múltiplas culturas ou à ideia

\footnotetext{
${ }^{9}$ Usamos a palavra criar aqui, mas não estamos dizendo que exista um complô de burgueses sentados numa mesa desenvolvendo a ideia de dupla verdade. O processo é complexo, difuso e cheio de continuidades e resistências. No entanto, defendemos que é a base material que sobredetermina a produção de ideias, de modo que sim, há ideias, em determinados períodos históricos, que são mais fáceis de aderir, pois coadunam e justificam o modo que a sociedade está organizada.

10 Apesar de afirmar que há semelhanças entre o nominalismo medieval, retratado na história do conde Belarmino, e o momento de decadência ideológica burguesa, Lukács faz questão de mostrar que no período medievo a teoria da dupla verdade garantia a possibilidade de investigação científica, no entanto agora estamos num polo invertido, visto que tal teoria agora tem o papel ideológico de deixar a religião livre. Para ampliar tal discussão sugerimos a leitura de Della Fonte (2010).

11 Para uma crítica mais aprofundada ao pragmatismo, sugerimos a leitura de Duayer (2010) e Moraes e Duayer (1998).
} 
de que não devemos incidir sobre a "crença" dos estudantes porque estaríamos sendo doutrinadores, celebramos e aceitamos, de partida, explicações mágicas e antropomorfizadas do mundo. O discurso que ao mesmo tempo não nega a ciência, mas não tem como horizonte levar ao limite sua concepção ontológica de uma realidade natural desantropomorfizada e desencantada, é um discurso que celebra a dupla verdade da ideologia burguesa. É a expressão máxima da razão fenomênica em detrimento da razão ontológica

É obvio que não se trata de defendermos aqui uma celebração abstrata à ciência moderna. Sedimentada no capitalismo, tal conhecimento não está imune às contradições. Assim, é evidente que muitas ideologias de cunho racista, machista etc. já foram incorporadas pela própria ciência e ganharam na história ar de cientificidade para justificar a própria ideologia burguesa (GOULD, 2014). Além disso, numa sociedade regida pela mercadoria, o desenvolvimento científico tecnológico também segue, muitas vezes sem preocupação, clara, com o meio ambiente e os recursos naturais atendendo às exigências do Capital. No entanto, nos parece equivocado identificar a ciência apenas com esse aspecto, esquecendo seu papel central na ampliação da concepção de mundo da humanidade (DUARTE, 2016).

Não temos dúvidas que muitas das pesquisas do ensino de ciências tomem para si um caráter progressista e tenham a intencionalidade de se colocar ao lado das minorias (ou das maiorias oprimidas). Mas, sem ter como horizonte resolver o problema pela raiz, temos aquilo que Moraes (1996) chama, concordando com Eagleton, de pessimismo libertário. Ele é libertário, porque reconhece a necessidade da crítica da miséria do atual sistema e aponta até para a necessidade de uma nova construção da sociedade, mas prevalece a consciência pessimista que apela para uma suposta onipotência da sociedade capitalista nos seus moldes atuais. "Uma espécie de esquizofrenia entre impulso e passividade, entre capacidade reconhecida e realização impossível, uma espécie de nulificação do sujeito do desejo, inutilmente emancipado da "razão" e da "objetividade" (MORAES, 1996, p. 48).

Falam-se em injustiças e fazem até uma crítica moralista ao capital, mas não assumem a sua possibilidade de superação. Muitos entendem que a luta de classes é algo da modernidade que já foi ultrapassado ou apenas assumem que o capitalismo precisa ser menos selvagem e melhorado, sem necessariamente deixar de existir, como podemos ver em uma publicação recente do Boaventura de Sousa Santos (2020) na sua obra "A cruel pedagogia do vírus":

Enquanto modelo social, o capitalismo não tem futuro. Em particular, a sua versão actualmente vigente - o neoliberalismo combinado com o dominio do capital financeiro - está social e politicamente desacreditada em face da tragédia a que conduziu a sociedade global e cujas consequências são mais evidentes do que nunca neste momento de crise humanitária global. O capitalismo poderá subsistir como um dos modelos económicos de produção, distribuição e consumo entre outros, mas não como único e muito menos como o que dita a lógica da aç̧ão do Estado e da sociedade. Ora, foi isto o que aconteceu nos últimos quarenta anos, sobretudo depois da queda do Muro de Berlim. Impôs-se a versão mais anti-social do 
capitalismo: o neoliberalismo crescentemente dominado pelo capital financeiro global. Esta versão do capitalismo sujeitou todas as áreas sociais - sobretudo saúde, educação e segurança social- ao modelo de negócio do capital, ou seja, a áreas de investimento privado que devem ser geridas de modo a gerar o máximo lucro para os investidores. Este modelo põe de lado qualquer lógica de serviço público, e com isso ignora os princípios de cidadania e os direitos humanos. Deixa para o Estado apenas as áreas residuais ou para clientelas pouco solventes (muitas vezes, a maioria da população) as áreas que não geram lucro (SANTOS, 2020, p. 24).

Para Santos (2020), o problema é essa versão do capitalismo que precisaria ser melhorada. Não o capitalismo como um todo, que, segundo o autor, poderia até subsistir. Santos não leva em conta a incontrolabilidade do capital e sua tendência universalizante conforme tem sido exposto por vários autores do campo marxista, como, por exemplo, Mésaros (2015) e Paniago (2001). Paniago, baseada em Mészáros (2015), demonstra por meio de seu trabalho que:

O capital se firmou na história como o "real (por mais perversamente reificado) sujeito em comando, permanecendo 'sempre capital' mesmo em suas instâncias personificadas". Somente substituindo o 'sistema orgânico' estabelecido como o controlador dominante e que a tudo abarca da reprodução societária” por um "sistema orgânico alternativo, genuinamente socialista", pode-se "restituir o poder alienado de comando sobre o trabalho ao próprio trabalho" (610/617). Nesse sentido, para se tornar o sujeito da, e ter o poder sobre, a totalidade do processo social, o trabalho tem que visar "a total erradicação do capital do metabolismo social enquanto comando sobre o trabalho - o que, por sua vez, é inconcebivel sem superar irreversivelmente a objetivação alienada do trabalho sob todos os seus aspectos, incluindo o Estado político - e a prevenção simultânea da personificação tanto do capital quanto do trabalho”.(619). O que significa superar todas as três dimensões fundamentais do sistema - capital, trabalho e Estado -, uma vez que "são materialmente constituidos e ligados um ao outro, e não simplesmente em uma base legal/politica" (PANIAGO, 2001, p. 169).

Diferente do proposto por Boaventura de Sousa Santos, a defesa que fazemos é que o horizonte para superação das mazelas postas, que se destacam em épocas de pandemia, só pode ser vencido via superação do capital.

Aceitar que o capitalismo é insuperável também está em correntes que se adjetivam de críticas. O multiculturalismo crítico de Mclaren também destaca a necessidade de convivermos, no mesmo espaço social com liberais, românticos etc., já que qualquer narrativa mestra (entre elas o comunismo) seria não democrática, como podemos ver na citação abaixo:

A crítica pós-modernista de resistência repudia a necessidade ou escolha de qualquer narrativa mestra, porque as narrativas mestras sugerem que existe apenas uma esfera pública, um valor, uma concepção de justiça que triunfa sobre as outras. 
O pós-modernismo de resistência sugere que, ao contrário, "esferas diferentes e concepções de justiça rivais devem acompanharem-se mutuamente (Murphy, 1991: 124). Em outras palavras, "liberais ou social-democratas, comunitários, desenvolvimentistas liberais ou humanistas, radicais e românticos devem encontrar maneiras de viver juntos no mesmo espaço social" (p.124). Isto não significa tentar condensá-los em uma polpa cultural homogênea, mas sim sugerir que deve haver uma multiplicação de justiças e uma concepção pluralista de justiça, política, ética e estética (MCLAREN, 1997, p. 83-84).

Trata-se, mais uma vez, de aceitar que o (neo)liberalismo deve continuar existindo, advogando que isso seria a forma mais plural de sociedade e, portanto, mais acolhedora e mais justa. Apesar de negar as metanarrativas, aceitam a universalidade do capitalismo, pois torna-o insuperável.

O objetivo de destacar o anticomunismo dessas abordagens é apenas reforçar que, seja qual for a concepção que, no limite, pluraliza a verdade ou evita disputar concepção de mundo na escola e fora dela, no final das contas, elas se silenciaram diante das raízes de uma sociedade desumanizadora e estão tomando posição, ainda que não de maneira intencional, pela classe dominante. Devemos, então, perguntar: qual o papel da escola e da educação científica dentro do materialismo histórico-dialético? Qual função do ensino de ciências diante dessa decadência ideológica burguesa que se manifesta de modo assustador nas fake news, as quais circulam nas redes sociais, mas que, via de regra, já estavam presentes, em diferentes graus, na perspectiva pós-moderna?

Defendemos uma educação que não se põe de joelhos para o capitalismo e que entende que é falso o dilema entre etnocentrismo e relativismo cultural (DUARTE, 2010). Assim, se queremos uma educação que contribua para superação deste mundo que está posto, precisamos não de um ensino de ciências que não queira incidir sobre a "crença" do aluno, mas de um ensino comprometido com a verdade e que tenha como horizonte a atuação do conhecimento verdadeiro na mudança da concepção de mundo do estudante. Uma educação que ensine o conteúdo no seu movimento lógico e histórico, mostrando suas contradições e seus vínculos com a prática social, superando o conhecimento aparente e a reificação da realidade. Um ensino concreto que mostre ao estudante o real tal qual ele é no seu movimento histórico e na sua relação com a prática transformadora humana.

Entendendo concepção de mundo como sendo "constituída por conhecimentos e posicionamentos valorativos acerca da vida, da sociedade, da natureza, das pessoas (incluindo-se a autoimagem) e das relações entre todos esses aspectos" (DUARTE, 2016, p. 99), lutamos para que o ensino incida de modo a produzir uma concepção que seja coerente com a verdade como adequação à realidade objetiva e, para isso, precisamos criar no estudante a necessidade de se apropriar, também, daquilo que a burguesia melhor construiu, às custas, inclusive, de muito sangue, suor e lágrimas da classe trabalhadora. No caso específico do ensino de ciências, passa por lutar por desenvolver em cada indivíduo singular 
uma concepção desendeuzada, desantropomorfizada, desencantada da natureza ${ }^{12}$. Mérito, como mostramos, da ciência moderna.

Ao mesmo tempo que é importante mostrar como a humanidade se apropriou desse conhecimento, as contradições envolvidas no uso e na apropriação, os valores e apagamentos feitos pela sociedade de classe. Concepções essas que podem permitir que entendamos de maneira desfetichizada o real no seu movimento histórico.

Isso não significa aceitar que a ciência ensinada na escola hoje é neutra e que trata-se do melhor conhecimento que podemos oferecer para classe trabalhadora. Isso não significa também assumir uma posição acrítica quanto a influência do próprio Capital e da ideologia liberal na produção do conhecimento científico. Trata-se, sim, de olhar para a ciência e para os outros conhecimentos e tirar deles aquilo que Saviani (2009) chama de bom senso quando trata do papel educativo. O bom senso é aquilo que se configura objetivo, porque descreve melhor a realidade, mas não é neutro como se quer o positivismo.

\begin{abstract}
Vale lembrar a distinção feita por Saviani (2008a) entre objetividade e neutralidade, mostrando que para negar os pressuposto positivista de neutralidade do conhecimento não é necessário negar a objetividade, pois isso seria cair na armadilha positivista que identifica as duas coisas. Marx, ao escrever O capital, não assumiu uma posição neutra em relação à sociedade capitalista e isso não o impediu de explicar de maneira cientifica e objetiva as leis que regem a dinâmica da economia burguesa. Assim, os conhecimentos cientificos situam-se no dominio da universalidade e buscam a desantropomorfização, restringindo, até onde seja possivel, a influência dos aspectos subjetivos na compreensão dos fenômenos (DUARTE, 2016, p. 74-75).
\end{abstract}

Isto permite que a crítica seja feita baseada, não naquilo que hoje institucionalmente chamamos de ciência, mas na possibilidade daquele conhecimento ser ou não verdadeiro na prática social global e, portanto, ter ou não caráter universal. Usar a realidade como balizador é muito importante para não vertemos o bebê com a água suja do banho e ao fazermos a crítica à ciência jogá-la fora.

A defesa da objetividade do conhecimento científico, sem esquecer suas contradições, não é feita só por nós deste manuscrito. Há trabalhos do ensino de ciências (ARTHURY; GARCIA, 2020; WESTPHA; PINHEIRO, 2004), ainda que não necessariamente pautados no materialismo histórico-dialético, que têm defendido a necessidade da objetividade científica sem deixar de reconhecer o caráter histórico em que esse conhecimento é produzido. Nas palavras de Arthury e Garcia (2020, p. 4):

\footnotetext{
12 Isso não significa, sob hipótese alguma, descartar a ideia de que o ser humano atua e transforma a natureza, como já discutido. Apenas destaca-se o entendimento claro de que o ser humano conhece/conheceu as "leis", formas e modelos da natureza que já existiam apesar dele e com ele, de modo que sua interferência tem sido cada vez mais intencional e menos aleatória.
} 
Pensamos então que tentativas de relativizar a ciência por sua natural interdependência do contexto em que é produzida, de modo a vilipendiar suas impressionantes conquistas reduzindo-as a conjuntos de explicações temporalmente arbitrárias é, no mínimo, um viés de confirmação, onde parte de seu procedente ataque à objetividade acaba por se tornar uma caricatura da instituição que procura atacar. Isso já seria um problema per se (...), mas somado aos movimentos anticientíficos (...), torna-se uma perigosa combinação.

Quando falamos de objetividade do conhecimento, não estamos defendendo um ensino insensível às questões culturais, visto que ser contra o relativismo não significa ser contra a variedade de culturas, como bem nos mostra Nanda (1999):

Uma coisa é aceitar um "Relativismo Cultural" que respeita a variedade da cultura humana; outra, inteiramente diferente, é adotar um relativismo que transforma esses valores culturais variados no único ou principal padrão de verdade, de modo que a verdade passa a ser simplesmente o que se ajusta a um dado sistema de crenças, ao invés de aquilo que descreve fielmente o mundo que existe independentemente de nossas crenças. Os críticos pós-modernistas da ciência tendem a adotar o segundo tipo de relativismo, que é indistinguivel do epistemológico. De acordo com o tipo de relativismo deles, uma teoria correspondente de verdade que inevitavelmente faz afirmações universalistas é violenta e responsável pela intolerância, o colonialismo e mesmo pelo totalitarismo (NANDA, 1999, p.100).

Diante de cada sujeito destinatário do processo educativo, os meios pelos quais o professor vai ensinar não devem ser violentos, nem devem ignorar as particularidades de cada povo, cultura etc., assim como não se trata de negar a possibilidade de cada indivíduo ter suas crenças religiosas, visto que, inclusive, são as condições materiais que condicionam a existência da religião ${ }^{13}$. No entanto, de partida, a escola não pode abandonar a disputa da concepção de mundo, ela precisa ter como princípio ético garantir o conhecimento produzido pela humanidade de caráter universalizante, verdadeiro, e que proporcione suprir o reino da necessidade para todos (equacionar as necessidades básicas para que a vida possa ser vivida, garantido, no mínimo, alimentos, água e abrigo para todos), abrindo espaço para um reino da liberdade pleno de diversidade e criatividade. Afinal, os diversos só podem existir como diversos a partir da sua reprodução material, que não pode/não deve estar sob o domínio de poucos, os "donos privados" dos meios de produção da nossa existência. Os diversos só são diversos, porque fazem parte de uma totalidade materialmente determinada e histórica, objetiva.

Esse conhecimento não precisa ser necessariamente europeu, asiático, africano, americano, ele precisa ser indispensável para explicar a realidade na sua essência

13 Um debate qualificado e não simplificado da relação do Marxismo com a religião pode ser encontrado em LOWY (1998) 
questionando as explicações mágicas, folclóricas e preconceituosas, mostrando os limites desses tipos de conhecimento dentro da racionalidade ontológica.

Em suma, se a escola e a divulgação científica têm algum papel no enfrentamento dessa era da pós-verdade, elas devem não ter medo de disputar a validade do conhecimento científico e os valores universais. É preciso travar uma batalha por cada consciência do educando, lutando para proporcionar uma concepção de mundo unitária, coerente, crítica, na qual se possa atingir o entendimento de que há uma cultura universal que não apaga as diferenças, mas não cede ao irracionalismo e ceticismo desse tempo.

Aos que chamam tal postura de dogmatismo e repetem os argumentos do movimento da escola sem partido, pensamos que a resposta de Saviani é suficiente para entendermos do que se trata a defesa pela educação científica que aqui fazemos:

educação é sempre um ato político, dada a subordinação real da educação à política. Dessa forma, agir como se a educação fosse isenta de influência política é uma forma eficiente de colocá-la a serviço dos interesses dominantes. E é esse o sentido do programa "escola sem partido" que visa, explicitamente, subtrair a escola do que seus adeptos entendem como "ideologias de esquerda", da influência dos partidos de esquerda colocando-a sob a influência da ideologia e dos partidos da direita, portanto, a serviço dos interesses dominantes. Ao proclamar a neutralidade da educação, o objetivo a atingir é o de estimular o idealismo dos professores fazendo-os acreditar na autonomia da educação em relação à política, o que os fará atingir o resultado inverso ao que estão buscando: em lugar de, como acreditam, estar preparando seus alunos para atuar de forma autônoma e crítica na sociedade, estarão formando para ajustá-los melhor à ordem existente e aceitar as condições de dominação às quais estão submetidos (SAVIANI, 2017, n. p).

A luta contra o Capital e uma educação que aponte para sua superação é a melhor forma que temos para atingir uma cultura universal realmente inclusiva que vai conseguir contemplar, sem mediação da mercadoria, aquilo de melhor em termos materiais e espirituais que a humanidade já produziu. A melhor ciência que podemos produzir ainda não está dada nesse tempo. Lutemos, inclusive na escola, por ela.

Somente assim [com a superação da propriedade privada] os indivíduos singulares são libertados das diversas limitações nacionais e locais, são postos em contato prático com a produção (incluindo a produção espiritual) do mundo inteiro e em condições de adquirir a capacidade de fruição dessa multifacetada produção de toda a terra (MARX; ENGELS, 2007, p. 40-41, acréscimo nosso).

\section{Considerações finais: destruindo o mito da medusa}

A situação que a humanidade vive neste momento é extremamente complicada. Diante de uma triste pandemia, a situação de exploração do trabalhador e, ao mesmo tempo da 
sua relevância para a produção da riqueza da humanidade por meio da sua força de trabalho, é colocada em evidência.

Esse mesmo cenário apontou que uma crítica abstrata à ciência feita pela pósmodernidade não consegue dar conta das demandas que aparecem na realidade. Assim, um conjunto de pesquisadores que passaram a década de 90 inteira questionando a ciência, precisam vir a público para pedir que se acredite em um conhecimento que foi chamado, de modo abstrato e como um todo, de eurocêntrico, dogmático e, intrinsecamente, colonizador.

Outros pesquisadores não negam a validade da ciência e até a defendem como uma verdade pragmática, mas lavam a mão diante das concepções de mundo das pessoas, destacando que o papel do ensino de ciências é apenas oferecer um conjunto de modelos e explicações que o sujeito pode acreditar ou não. Sob o manto do não dogmatismo, lavam as mãos diante da importância que as ciências têm para o modo como os sujeitos veem a realidade e "acreditam" na realidade. Ao fazer isso, não concebem nenhuma intencionalidade transformadora radical da realidade para o ensino de ciências.

O que há de comum nestas perspectivas é que, de um modo ou de outro, elas aceitam que o capitalismo é o fim da história, que a única opção é render-se a essa forma de reproduzir a realidade. Sem uma crítica radical ao sistema, apenas constatam que o mundo está caótico e que as pessoas não mais acreditam na razão e na realidade. Tratam fenômenos de mesma base material como se fossem mero acaso. Tratam a ascensão de governos fascistas como se fossem mero desvio de um sistema que precisa de ajuste e militância local. Uma visão universal de comunismo seria totalitária.

O que nos propusermos neste texto é ir na contracorrente dessa visão. No nosso entender, o marxismo, considerado por muitos ultrapassado e morto, ainda tem as melhores respostas para a situação que vivemos. Desse modo, supondo a não familiaridade do leitor com esse referencial, detalhamos a categoria trabalho e como ela é fundante do ser social. Discutido isso, passamos pela discussão da prática social como critério de verdade, falando de como o materialismo histórico-dialético supera por incorporação a razão fenomênica em direção à razão ontológica.

Por fim, retomamos esse conceito tentando defender uma educação científica preocupada com a verdade e que deseja incidir, de fato, sobre a concepção de mundo do estudante, apontando para uma sociedade justa que não se realizará simplesmente por vontade divina ou palavras de ordem. Uma sociedade, de fato, antiracista, antimachista que respeite a diversidade cultural só pode ser construída fora da égide de uma sociedade de classes, que tem como corolário a propriedade privada dos meios fundamentais de produção da nossa existência, a qual proporciona um sistema que admite a exploração dos trabalhadores e o valor de troca das mercadorias como horizonte único, razão última das diversas formas de opressão na atualidade.

A pós-modernidade criou uma espécie de mito de que a sociedade capitalista seria como uma medusa, da mitologia grega, e, assim, não podemos olhar para ela e enfrentá-la 
diretamente, pois viraríamos pedra. Então, nos resta ou atacarmos cegamente o monstro de olho fechado ou ficarmos olhando por reflexos de espelhos fragmentados, esperando a hora certa de atacar esse inimigo, hora essa que nunca chega. Diante disso, a pós-modernidade ou aceita a rendição cega diante do capital ou assume que cada agrupamento de sujeitos e culturas deve ficar olhando o mundo a partir da sua ótica e atacar o inimigo pela sua via.

Diferente da pós-modernidade, esse artigo, com base no materialismo históricodialético, defende que a medusa não deve ser vista como um monstro em si com poderes assustadores que transforma em estátua de pedra quando se olha de frente. O capital não é uma entidade mística e a-histórica, ela é uma forma humana de se organizar, produzir riqueza, contraditória, que pode ser superada diante da luta organizada dos trabalhadores. É o conhecimento verdadeiro do mundo natural e social que a escola pode ajudar a oferecer, que pode nos mostrar que o medo da medusa paralisa e petrifica mais do que olhar nos olhos dela e destruí-la.

Diante da barbárie e do cenário da pós-verdade que vivemos, a luta pela verdade não neutra é a boa arma que nós temos. Não podemos ficar indiferentes.

\section{Referências bibliográficas}

ABRANTES, P. C. C. Imagens de natureza e imagens de ciência. Campinas: Papirus, 1998.

ANDERSON, P. As origens do pós-modernismo. Tradução: Marcus Penchel. Rio de Janeiro: Jorge Zahar, 1999.

ANDERY, M. A. et al. Para compreender a ciência: uma perspectiva histórica. São Paulo: Espaço e Tempo, 1995.

ARTHURY, L. H. M.; GARCIA, J. O. Em prol do realismo científico no ensino. Ciência \& Educação, v. 26, p. 1-14, 2020.

BAPTISTA, G. C. S. Do cientificismo ao diálogo intercultural na formação do professor e ensino de ciências. Interações, v. 31, p. 28-53, 2014.

BARATA-MOURA, J. Ideologia e Prática. Lisboa: Caminho, 1978.

BARATA-MOURA, J. Prática: Para uma aclaração do seu sentido como categoria filosófica. Lisboa: Edições Colibri, 1994.

COBERN, W; LOVING, C. Defining science in a multicultural world: implications for science education. Science Education, New York, v. 85, n. 1, p. 50-67, 2001. 
COBERN, W. W. Worldview theory and conceptual change in science education. Science Education, v. 80, n. 5, p. 579-610, 1996.

D’ANCONA, M. Pós-verdade: a nova guerra contra os fatos em tempos de fake news. Barueri: Faro Editorial, 2018.

DAVIS, A. Mulheres, raça e classe. São Paulo: Boitempo, 2016.

DELLA FONTE, S. S. Considerações sobre o ceticismo contemporâneo a partir da ontologia e gnosiologia marxista. In: DUARTE, Newton; FONTE, Sandra. Arte, conhecimento e paixão na formação humana: sete ensaios de pedagogia histórico-crítica. Campinas: Autores Associados, 2010.

DUARTE, N. (Org.). Sobre o construtivismo: contribuições a uma análise crítica. 2. ed. Campinas: Autores Associados, 2005.

DUARTE, N. Crítica às apropriações neoliberais e pós-modernas da teoria vigotskiana. 2. ed. Campinas: Autores Associados, 2001.

DUARTE, N. Por uma educação que supere a falsa escolha entre etnocentrismo e relativismo cultural. In: DUARTE, N.; FONTE, S. Arte, conhecimento e paixão na formação humana: sete ensaios de pedagogia histórico-crítica. Campinas: Autores Associados, 2010.

DUARTE, N. Os conteúdos escolares e a ressurreição dos mortos: contribuição à teoria histórico-crítica do currículo. Campinas: Autores Associados, 2016.

DUAYER, M. Relativismo, certeza e conformismo: para uma crítica das filosofias da perenidade do capital. Revista da Sociedade Brasileira de Economia Política, v. 27, p. 5883, 2010.

EL-JAICK, A. P. Pós-verdade, ficção, fake news. Fragmentum, n. 53, p. 41-57, 2019.

GALILEU, G. O Ensaiador. São Paulo: Nova Cultura. Coleção os Pensadores, 1987.

GOULD, S. J. A Falsa Medida do Homem. 3. ed. São Paulo: Martins Fontes, 2014.

HAIDER, A. Armadilha da Identidade: raça e classe nos dias de hoje. São Paulo: Veneta, 2019. 
KOSIK, K. Dialética do concreto. Rio de Janeiro: Paz e Terra, 1976.

LANDI FAZZIO, G.; MANOEL, J. (Orgs.) A Revolução Africana: uma antologia do pensamento marxista. São Paulo: Autonomia Literária, 2019. p. 258.

LÊNIN, V. I. Sobre a educação. Lisboa: Seara Nova, 1977. v. 1.

LESSA, S. Possibilidade, lei e acaso: os físicos e seus incríveis cíclotrons. Disponível em: $<$ http:// www.sergiolessa.com/>. Acesso em: nov. 2019.

LESSA, S.; TONET, I. Introdução à Filosofia de Marx. São Paulo: Editora Expressão Popular, 2006.

LIMA, N. W. et al. Educação em Ciências nos Tempos de Pós-Verdade: Reflexões Metafísicas a partir dos Estudos das Ciências de Bruno Latour. Revista Brasileira de Pesquisa em Educação em Ciências, p. 155-189, 2019.

LÖWY, M. Marx e Engels como sociólogos da religião. Lua Nova: Revista de Cultura e Política, n. 43, p. 157-170, 1998.

LUKÁCS, G. Prolegômenos para uma ontologia do ser social: questões de princípios para uma ontologia hoje tornada possível. São Paulo: Boitempo, 2010.

LUKÁCS, G. Para uma ontologia do ser social I. 2. ed. São Paulo: Boitempo, 2018.

LYOTARD, J. A condição pós-moderna. Lisboa: Gradiva, 1997.

MACHEL, S. Estabelecer o poder popular para servir as massas. Centro de informação e documentação anticolonial (CIDAC), 1974.

MARX, K. Manuscritos econômico-filosóficos-Terceiros manuscritos: propriedade privada e comunismo. Disponível em: <https://www.marxists.org/portugues/marx/1844/ manuscritos/index.htm>. Acesso em: 20 jan. 2020.

MARX, K. O Capital (crítica da economia política): o processo de produção do capital. Civilização Brasileira, Livro 1, 1980. v. 1. 
MARX, K.; ENGELS, F. A ideologia alemã: crítica da mais recente filosofia alemã em seus representantes Feuerbach, B. Bauer e Stirner, e do socialismo alemão em seus diferentes profetas (1845-1846). São Paulo: Boitempo, 2007.

MCINTYRE, L. Pos-truth. Cambridge (MA): The MIT Press, 2018.

MCLAREN, P. Multiculturalismo crítico. São Paulo: Cortez Editora, 1997.

MCNALLY, D. Língua, história e luta de classe. In: WOOD, E. M.; FOSTER, J. B. (Org.). Em defesa da história: marxismo e pós-modernismo. Rio de Janeiro: Jorge Zahar. 1999.

MÉSZÁROS, I. Para além do capital: rumo a uma teoria da transição. São Paulo: Boitempo, 2006.

MORADILLO, E. F. A dimensão prática na licenciatura em química da UFBA: possibilidades para além da formação empírico-analítica. 264 f. 2010 . Tese (Doutorado) Instituto de Física, Universidade Federal da Bahia, Salvador.

MORAES, M. C. M. Os "pós-ismos" e outras querelas ideológicas. Perspectiva, Florianópolis, UFSC/CED, NUP, n. 24 p. 45-59, 1996.

MORAES, M. C. M. (Org.). Iluminismo às avessas: produção de conhecimento e políticas de formação docente. Rio de Janeiro: DP\&A, 2003.

MORAES, M. C. M. O renovado conservadorismo da agenda pós-moderna. Cadernos de Pesquisa, v. 34, n. 122, p. 337-357, 2004.

MORAES, M. C. M.; DUAYER, M. História, estórias: morte do" real" ou derrota do pensamento? Perspectiva, v. 16, n. 29, p. 63-74, 1998.

NANDA, M. Contra a destruição/desconstrução da ciência: histórias cautelares do terceiro mundo. In: WOOD, E. M.; FOSTER, J. B. (Org.). Em defesa da história: marxismo e pósmodernismo. Rio de Janeiro: Jorge Zahar, 1999. p. 84-106.

NETTO, J. P. Relendo a teoria marxista da história. Disponível em: $<$ https://marxismo21.org/wp-content/uploads/2015/10/Teoria-social-JP-Netto.pdf $>$. Acesso em: 20 jan. 2020.

OLIVEIRA, M. A. A filosofia na crise da modernidade. São Paulo: Loyola, 2001. 
PAIVA, A. S.; MARTINS, K. V.; ALMEIDA, R. O. Ciência e outras culturas proposições para o ensino de Ciências e Biologia. Congresso ibeamericano de investigação qualitativa, v. 2, 2015.

PANIAGO, M. C. S. A incontrolabilidade ontológica do capital. Um estudo de Beyond Capital de I. Mészaros. 2001. Tese (Doutorado em Serviço Social) - Universidade Federal do Rio de Janeiro, Rio de Janeiro.

PANIAGO, M. C. S. Mészáros e a incontrolabilidade do capital. São Paulo: Instituto Lukács, 2012.

SAFFIOTI, H. A Mulher na Sociedade de Classe: Mito e Realidade. Petrópolis: Vozes, 1976.

SANTOS, B. S. Pela mão de Alice: O Social e o Político na Pós-modernidade. 14. ed. São Paulo: Cortez, 2013.

SAVIANI, D. "Escola sem Partido": o que isso significa? 2017. Disponível em: $<$ https://vermelho.org.br/2017/09/08/dermerval-saviani-escola-sem-partido-o-que-issosignifica/>.

OKI, M. C. M. A história da química possibilitando o conhecimento da natureza da ciência e uma abordagem contextualizada de conceitos químicos: um estudo de caso numa disciplina do curso de química da UFBA. 2006. Tese (Doutorado em Educação) - Faculdade de Educação, Universidade Federal da Bahia, Salvador.

OKI, M. C. M. Controvérsias sobre o atomismo no século XIX. Química Nova, São Paulo, v. 32, n. 4, p. 1072-1082, 2009.

TEIXEIRA, P. Evolução $\mathrm{x}$ criacionismo na escola: quais os objetivos do ensino de Biologia. In: ENDIPE, XVII, 2016, Fortaleza. Didática e Prática de Ensino na relação com a Sociedade. Anais... Fortaleza: EdUECE, p. 2092-20102, 2016.

TESICH, S. A Government of Lies. The Nation, v. 254, n. 1, p. 12-14, 1992.

TONET, I. Modernidade, Pós-Modernidade e Razão. Disponível em:

$<$ http://ivotonet.xp3.biz/arquivos/MODERNIDADE_POSMODERNIDADE_E_RAZAO.pdf> Acesso em: 20. jan. 2020. 
TONET, I. Método científico: uma abordagem ontológica. São Paulo: Instituto Lukács, 2013.

WOOD, E. M.; FOSTER, J. B. (Org.). Em defesa da história: marxismo e pós-modernismo. Rio de Janeiro: Jorge Zahar. 1999.

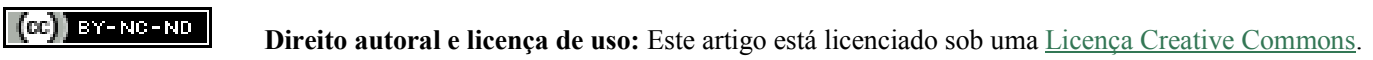

